\title{
WELFARE AND POVERTY STATUS AMONG MAIZE FARMING HOUSEHOLDS IN LERE LOCAL GOVERNMENT AREA OF KADUNA STATE, NIGERIA
}

\author{
Balogun O.S. ${ }^{1 *}$, Olorukooba M.M. ${ }^{2}$, Balogun O.L. ${ }^{3}$, Alabi O.F. ${ }^{1}$, Tor Lawrence G. ${ }^{1}$, \\ Nwahia O.C. ${ }^{4}$, Bala U.J. ${ }^{2}$ \\ ${ }^{1}$ Department of Agricultural Extension and Management, Federal College of Forestry \\ Mechanization, Afaka, Nigeria \\ ${ }^{2}$ Department of Crop Production, Federal College of Forestry Mechanization, Afaka, Nigeria \\ ${ }^{3}$ Department of Agriculture \& Industrial Technology, School of Science and Technology, \\ Babcock University, llishan-Remo, Nigeria \\ ${ }^{4}$ Department of Agricultural Economics, Ahmadu Bello University, Zaria, Nigeria \\ *E-mail: baaseg2006@yahoo.com
}

\begin{abstract}
Nigeria has had a persistent socio-economically underdeveloped in the midst of immense mineral resources with two third of her population still trapped in poverty. This study therefore profiles the welfare and inequality status of farming households in Lere L.G.A of Kaduna State using a multistage sampling technique. Primary data was collected from 165 maize farming households. Data was analyzed using descriptive statistics, FGT measures of poverty and Logistic regression Model. The results show that majority of the farmers had poor access to electricity;. Farmers largely patronize alternative medication because of poverty. Poverty incidence was high with a value of $61.96 \%$, a poverty Gap of 0.3329 and a poverty severity index 0.2321 . Diversity in spending among the maize farming households was also high with a Gini index of 0.5493 . Age $(\beta=-0.018 ; p<0.01)$ of maize farmers, household's size $(\beta=0.036 ; p<0.1)$; Primary occupation $(\beta=0.171 ; p<0.1)$ and status of education $(\beta=-0.05 ; p<0.05)$ were found to influence the log likelihood of a maize farming household poverty status. The study recommends sustainable poverty reduction through improving the capabilities of the poor farmers. . Furthermore, coordination on proper family planning for birth control should be carried out for the farming families in the study area to boost their welfare.
\end{abstract}

\section{KEY WORDS}

Consumption expenditure, determinants, Greer and Thorbeecke (FGT) Index, Gini Index.

Poverty has been in existence for many years and continues to exist in many countries. The International Development Community (IDC) noted that agriculture is the engine of growth and poverty reduction in countries where it is the main occupation of the larger proportion of the people (Balogun et al., 2020). The eradication of poverty in all its forms and dimensions is the world's greatest global challenge. Sub-Sahara Africa is reported to have the largest population suffering from hunger (FAO, 2015). The reasons adduce to increasing poverty level in most African countries including Nigeria are; conflicts, civil war, political instability, drought, high external debt and rapid rise and spread of HIV/AIDS (Akinlade, 2015). Poverty is more than consideration of income alone; good life or well-being is multidimensional, with both material and psychological aspects. People living in poverty according to the assertion of the World Bank, (2000) feel a bypass of new economic privileges via insufficient access to market, denial of resources for fair participation and/or hindrance to a higher level of society.

Poverty as a composite phenomenon has been examined by many scholars and development associates in diverse ways. Though there have been various versions of definitions of the term poverty (Abdul-Mamin and Shamshiry, 2014) over the decades, there is, however, no specific generally accepted definition of poverty due to its multifacetedness. Following the definition given by Abdul-Mamin and Shamshiry (2014), poverty is defined as a diversity of deprivations a person or household experiences simultaneously or separately 
that stifles the person's or households' abilities to function, live a life of purpose and fulfillment, and be productive in the society. These deprivations could be economic, social, political, cultural, physical or spiritual. From this definition and various perspectives, poverty is generally accepted as a phenomenon which goes beyond income and consumption standard but includes a state of wellbeing, which is economically, morally and socially unacceptable, caused by various dynamic interactions which make some better-off and others worse off.

In Nigeria, the rural areas are the most affected by poverty. Majority of those in poverty are disproportionately located in the rural areas, where they are primarily engaged in agricultural production and allied activities (NBS, 2008; Omonona,2009). Therefore farmers are likely to be affected than any other sub-group of the society. The higher incidence of poverty in Nigeria in rural areas has been traced to environmental problem associated with agricultural production, high vulnerability, high fertility rate, lack of access to improved seeds and inputs and poor developed social infrastructural facilities among others. Other factors that characterizes the poor as observed by (Oyekale and Okunmadewa, 2008 and Ataguba et al, 2011), includes factors such as level of education, employment status, house hold size, religion, mental status, household size, religion, and marital status. Ademiluyi, (2014), noted that welfare represents people's standard of living. In theory, households' consumption expenditure on food and non-food are good indicators of welfare.

Poverty in Nigeria over the years has consistently assumed an evolutionary trajectory. This indicates that a significant number of people in Nigeria are still living below the poverty line in spite of seemingly concerted efforts by subsequent governments to reduce poverty, Nigerians are getting poorer by the day (Obadan 2001; Ewrudjakpor 2005, Maduagwu 2007). Empirical findings (NBS, 2008) asserted that rural areas in Nigeria are prone to higher incidence of poverty and deprivations than the urban centers largely because urban residence has a strong impact in reducing the risk of poverty than the rural areas, due to the provision of several basic services such as electricity, water, and sanitation. Also, urban areas tend to offer more jobs opportunities. This implies that farmers who form the bulk of the rural population are poor.

Understanding the various determinants of poverty (i.e urban and rural poverty) presents a set of issues distinct from general poverty analysis and sometimes requires special attention for adequate policy development. Yusuf et al.,(2008) noted that to reduce poverty, policy makers first need to know the incidence, depth, and severity of poverty. The use of depth and severity measures of poverty is important as these two additional measures provides information on the depth and severity of poverty and hence compliment the poverty spread pictures painted by headcount ratio. Furthermore, seeing statistics and the trends in poverty (as commonly presented in most studies) helps us to observe that what happened to poverty in different periods and also the decomposition of poverty in different years gives us a more appropriate picture of the incidence of poverty.

This knowledge is useful because it informs us whether poverty is increasing or decreasing overtime. However, this information does not provide us enough details of the causes of poverty. For instance, is poverty high due to low education attainment or large family size or due to any other reason? For these reasons, research about the determinants of poverty that are positively or negatively linked with the poverty status becomes very important. To this end, this study is extremely useful because we have to understand the main determinants of poverty before designing the most efficient policy to reduce poverty in the country, region, and state or even in subsectors of the economy. Thus, the following research questions were addressed by the study. What is the poverty and welfare profile of the rural and urban farming households in the Locality? What are the determinants of farmers' welfare and poverty status among the maize faming households in the study area?

\section{METHODS OF RESEARCH}

The study was conducted in Lere local government (LGA), Kaduna state. The local government area was created in 1989, carved out of the former Saminaka LGA which was 
divided into two LGAs (Lere and Kauru) during the military administration. The local government covers about 256sqkm, with a projected (2020) population of about 498,919 (KBS, 2020). The local government is situated on the eastern part of Kaduna state; its geographical coordinates are $10^{\circ} 23^{\prime} 0^{\prime \prime}$ North, $8^{\circ} 35^{\prime} 0^{\prime \prime}$ East. It shares common border with Bauchi and Plateau state in the east. The climate is considerably good for arable crops; it falls in the guinea savannah vegetation zone. The major economic activities of its people are farming, rearing of animals/cattle, trading, fisheries and civil service. Rainfall extends to early October while the harmattan set in the mid October, November and extends to February (Balogun et al, 2020). Major towns are Saminaka, Ungwan bawa, Lere, Yar kasuwa, Danalhaji, Kahugu, Gure, Garun kurama, Kayarda and Ramin kura. (Balogun. et al., 2020).

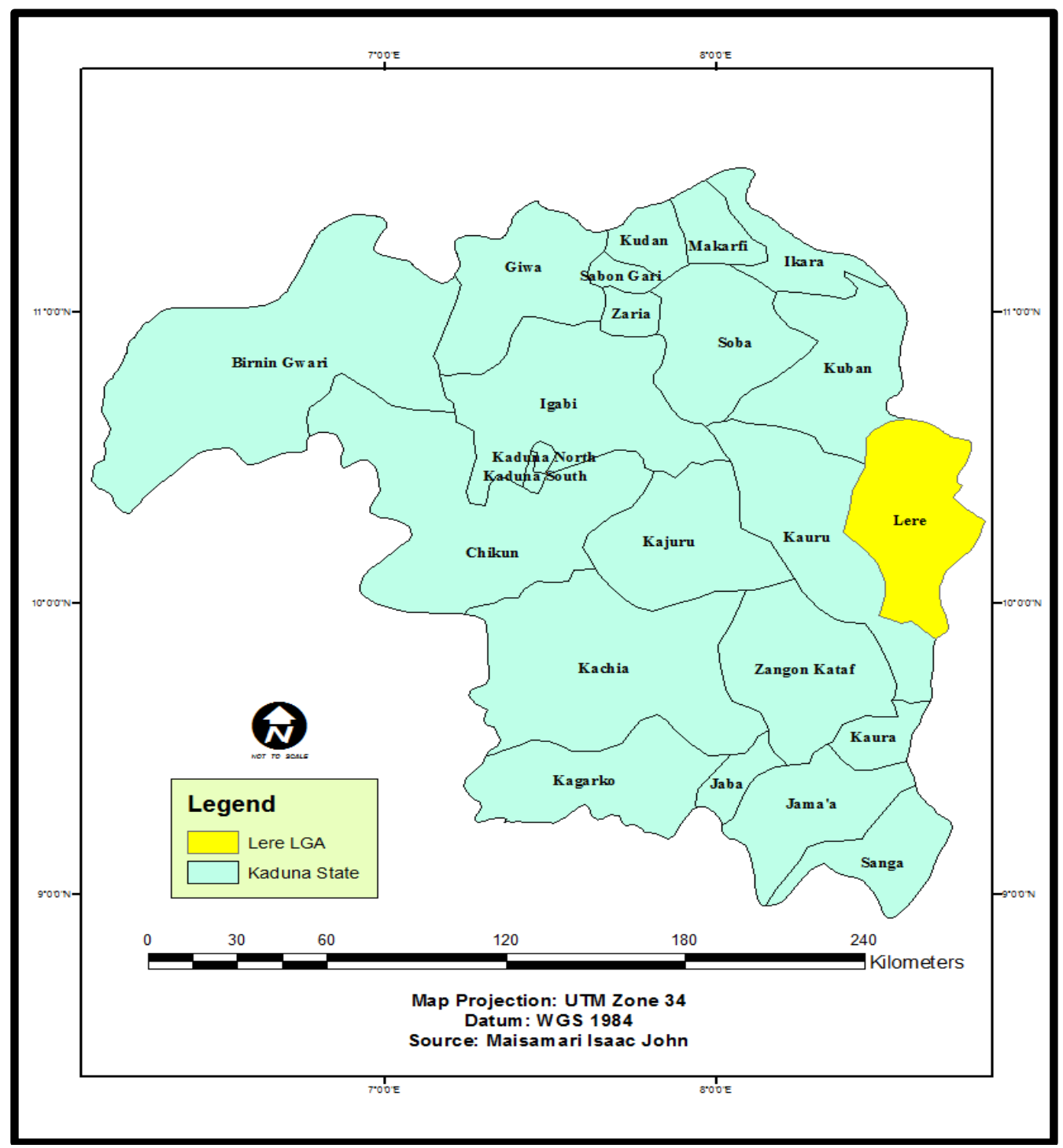

Figure 1 - Map Showing Kaduna State Local Government Areas

Primary data were used for the study. With multistage sampling technique, the L.G.A was stratified into rural and urban localities to ensure adequate representation of both the rural and urban farmers. Five (5) out of the major towns and villages (two urban(Saminaka and Yakasua) and three rural(Gure, Lere, and Fadan Kahugu) were selected for the study. One hundred and sixty five (165) farming households were randomly selected and administered with well-structured questionnaire carefully designed to capture three dimensions of deprivation viz (Education, Health and Standard of living) with ten indicators (Viz: years of schooling, school attendance, Child mortality Nutrition electricity, sanitation 
water, floor, cooking fuel and Assets). Descriptive statistics, Alkire and Foster methodology (2008) and Binary models (Logit regression) were used to analyze the data.

Hypothesis:

- Ho: The working hypothesis is that the selected demographic characteristic of the maize farmers does not significantly influence their poverty in the study area.

Descriptive statistics, Foster, Greer, and Thorbecke (FGT, 1984) measures of poverty Logit models were employed for the analysis. Per capital consumption expenditure was used as proxy in this study for income in the estimation of poverty to control for overstating or understating household income (Omonona, et al 2014; Akinlade, et al, 2015).

Model Specification:

$$
\begin{aligned}
& P C E=\frac{T C E}{H H S} \\
& M P C H=\frac{T H H E}{T N R} \\
& Z=(2 / 3) M P C H E
\end{aligned}
$$

Where: $P C E=$ Per Capita Expenditure, $T C E=$ Total Consumption Expenditure, $H H S=$ Household Size, $M P C H E=$ Mean per Capita Expenditure, $T N R=$ Total Number of Respondents, $T H H E=$ Total Household Expenditure, $Z=$ Poverty Line.

The method of Foster, Greer and Thorbeeke (FGT) measure were used to evaluate the poverty statuses among the urban farmers. This is generally specified as:

$$
P_{\alpha}=\frac{1}{n} \sum_{i=1}^{q}\left(\frac{Z_{i}-Y_{i}}{Z_{i}}\right)^{\alpha}=\frac{q}{n}
$$

Where: $\mathrm{n}=$ number of households in group, $\mathrm{q}=$ the number of poor household, $Z_{i}=$ poverty line defined as $2 / 3$ of mean annual per capita expenditure; $Y_{i}=$ the per capita expenditure (PCE) of the $\mathrm{i}^{\text {th }}$ household, (Poverty indicator/welfare index per capita); $\alpha=$ degree of poverty aversion $(0,1$ and 2$), Z_{i}-Y_{i}=$ poverty gap of household ith; $\frac{Z_{i}-Y_{i}}{Z_{i}}=$ Poverty gap ratio.

Poverty headcount index ( $\alpha=0$ measures poverty incidence), $\alpha=1$ and $\alpha=2$ for poverty gap index and squared poverty gap measuring severity of poverty among the women farmers, i.e. the depth of poverty and inequality among the poor.

Inequality of households was achieved by using Gini Coefficient. The method of Mordduch and Sicular (2002) adopted by Akinlade et al., (2015) noted that where incomes are considered so that $Y_{1} \leq Y_{2} \leq Y_{3}, \ldots . \leq Y_{4}$ The Gini coefficient is given by:

$$
\begin{gathered}
I_{\text {Gini }}(Y)=\sum_{i}^{n} \alpha_{i}(Y) Y_{i} \text { and } a_{i}(Y)=\frac{2}{n^{2} \mu}\left\{i=\frac{n+1}{2}\right\} \\
I_{\text {Gini }}(Y)=\frac{2}{n^{2} \mu}\left\{i=\frac{n+1}{2}\right\}
\end{gathered}
$$

Where: $\mathrm{n}=$ number of observations, $\mu=$ the mean of the distribution, $Y_{i}=$ the income of the ith household, $a_{i}(Y)_{i}=$ the weight, $i=$ corresponding rank of the total income.

Poverty status Correlates are normally analyzed using poverty profiles or poverty status regression. Various regression approaches used in modeling determinants of poverty includes Ordinary Least Squares (OLS), Tobit models, Probit and Logit Models While poverty profile identify the characteristics of the poor using a tabulation approach and usually do not allow more than one correlates of the poor to vary simultaneously, in contrast, poverty status regression analysis correlates of poverty in a multivariate framework (Yusuf et al., 2008). The OLS assumes a continuous dependent variable in the case of poverty (Omonona, 2009), but the response is binomial process taking values of 1 for poor and 0 for non-poor or vice vasa in case of Logit and Probit models which are often preferred when taking into account the influence of explanatory variables on poverty status (Park, 2010,; Akinlade., 2015). The Tobit model is mostly used when the intension is to differentiate between the extent of poverty and poor (Omonona,2001, Adejobi,2004; Amaza et al., 2007; Balogun et al.,, 2011; Akinlade et 
al., 2015). In this study, correlates of poverty were isolated using Logistic regression in line with the approach used by Yusuf et al., (2008). The Logistic model is specified as:

$$
P_{i}=1 / 1+e^{-z i} f\left(Z_{i}\right)
$$

Where: $P_{i}$ is the probability that dependent variable $Y_{i}=(\mathrm{i}=1,2,3 \ldots \ldots \mathrm{n})$ will be poor. Index $Z_{i}$ is a random variable which predicts the probability of a household been poor or non-poor.

$$
P_{i}=e^{z i} / 1+e^{z i}
$$

The ith observation, a household will be:

$$
Z_{i}=\ln P_{I} / 1-P_{i}=\delta_{0}+\sum \delta_{0}
$$

Therefore, $\ln ((P / 1-P)=1$ if the household is poor while $\ln ((P / 1-P)=0$, if otherwise i.e non-poor.

The implicit form of the model is specified as:

$$
Y=\delta_{0}+\delta_{1} X_{1}+\delta_{2} X_{2} \ldots \ldots \ldots \ldots \ldots \ldots \delta_{n} X_{n}
$$

The explanatory variables are: $X_{1}=$ Age (years), $X_{2}=$ Household size (Number of People per Household), $X_{3}=$ Primary Occupation (Farming 1, 0 otherwise), $X_{4}=$ Farming Experience (years in farming), $X_{5}=$ Marital Status (Married 1, Otherwise 0), $X_{6}=$ Education (Years of formal schooling), $X_{7}=$ Religion (Christianity 1, Otherwise 0), $X_{8}=$ Farm Size $(\mathrm{Ha})$, $X_{9}=$ Gender.

\section{RESULTS AND DISCUSSION}

Table 1 below presents the overview of farming household's distribution of socioeconomic characteristics reflecting housing conditions in the study area. Although about 82 $(49.7 \%)$ of the farmers were connected to the National grid, about $71(43.03 \%)$ of the farmers had to rely mainly on personal generators while $72(43.62 \%)$ rely on candle and bush lanterns for lightening their homes. Only 22 (13.35\%) rely on National Electric Power Authority for light source because of its instability.

Table 1 - Housing characteristics of the respondents

\begin{tabular}{lll}
\hline Variables & Frequency & Percentage \\
\hline Access to good electricity & & \\
Yes & 55 & 33.33 \\
No & 110 & 66.67 \\
Main lightening source & & 38.78 \\
Bush lantern & 64 & 4.84 \\
Candle & 8 & 43.03 \\
Generator & 71 & 13.35 \\
NEPA & 22 & 49.70 \\
Town/village connection to National grid & & 50.30 \\
Yes & 82 & 1.14 \\
No & 83 & 28.48 \\
Housing condition & & 70.30 \\
Tent & 2 & 7.88 \\
Mud building & 47 & 92.12 \\
Block wall & 116 & \\
Roofing type & & 5.46 \\
Thatched grass & & 8.48 \\
Finc roof & & 75.15 \\
Carpet & 13 & 10.91 \\
Mud & 152 & 100 \\
Cemented & & \\
Tiled & 9 & 14 \\
Total & 124 & 18 \\
\hline
\end{tabular}

Source: Field Survey, 2020. 
This reiterates the poor access to electricity as reported by $110 /(66 \%)$ of the farmers. On the structures and conditions of building in the environment, those who used modern materials such as block walls, Zinc roof, and cemented and tiled floors constituted $70.3 \%$, $92.12 \%$, and $75.15 \%$ respectively showing the farmers' personal effort at living in relatively conducive homes.

On sanitation, the instruments used to examine these are, types of toilet facilities, and availability of safe drinking water. The respondents were then asked to rank these instruments. Table 2 below presents the respondents description of their sanitation conditions. The results revealed that most $85(51.52 \%)$ of the farmers had access to modern water system toilets. Also, 134(81.21\%) had access to safe drinking water in form of pipe born water, bore hole and covered well. Slightly less than half of the farming households 74 $(48.85 \%)$ had access to bore holes water for drinking.

Table 2 - Sanitation description of the respondents

\begin{tabular}{lll}
\hline Variable & Frequency & Percentage \\
\hline Type of Toilet Facilities & & \\
Public & 19 & 15143 \\
Local latrine/pit toilet & 61 & 36.97 \\
Modern toilet water system & 85 & 51.52 \\
Availability of Safe Drinking Water & 134 & 81.21 \\
Yes & 31 & 18.78 \\
No & & \\
Water Source and Type & 41 & 28.85 \\
Open well & 20 & 12.12 \\
Covered well & 74 & 48.85 \\
Bore hole & 30 & 10.10 \\
Pipe born water & & \\
Sanitation Condition & 40 & 24.24 \\
Fair & 93 & 56.36 \\
Good & 32 & 19.40 \\
Very good & 105 & 100 \\
\hline Total & &
\end{tabular}

Source: Field Survey.

Table 3 shows the health description of the sampled respondents' access and Utilization of health facilities. The results revealed that most $134(81.21 \%)$ of the farmers had access to modern health facilities such as clinic, medical stores, private and General Hospitals with $38.79 \%$ relying on clinics, $9.09 \%$ rely on medicine stores, while $73(44.23 \%)$ and $13(7.89 \%)$ respectively rely on private and government hospitals. Furthermore, $69(41.90 \%)$ farmers reported cases of child mortality with high incidence among children between 1-2 years old. It was observed that child mortality decreases with age. The use of alternative medicine is very rampant among the farmers. About $83(50.03 \%)$ patronized native medicines for reasons such as affordability, 53.01\% of those using alternative medicine believe it is more effective while $31.52 \%$ use it because of poverty related reasons. The peculiarities of illness are responsible for patronage of alternative medicine by about $8.43 \%$ of the farmers.

The elasticity of each of the poverty measures with respect to the mean income (growth elasticity) and changes in inequality (Gini elasticity) are presented in Table 4. Poverty measures in this study show a more responsiveness to changes in inequality with values (0.202782), (1.5515) and 2.8499) than to changes in income with $(-0.6843),(-08612)$ and $(0.8684)$. This means that pro-poor policies geared towards income redistribution will impact the maize farmers significantly. This agrees with the findings of Yusuf et al, (2008) which revealed that reducing income inequality has a larger positive impact on poverty than growth. In this case, it was assumed that the impact of growth is independent of the nature of income distribution. Most low income people in most countries are more likely to be poor; therefore policies that enhance redistribution of income that reduces inequality would uplift more individuals around the poverty line. This subsequently increases their welfare and 
reduces poverty. Also, the farming households in the study area have a poverty incidence of about $61.96 \%$, a poverty Gap of 0.3329 and a poverty severity index 0.2321 . According to Anyanwu, (2005), the poverty incidence is a measure of poverty which refers to the proportion of families with per capita income less than the per capita poverty threshold to the total number of families. Moreover, the poverty depth (poverty Gap of 0.3329 ) indicates how far below the poverty line the average poor household's income falls, and is measured by the poverty gap ratio which is defined as the total income shortfall, expressed in proportion to the poverty line, of families with income below the poverty threshold, divided by the total number of families. The severity of poverty obtained (poverty severity index 0.2321 ) is the poverty measurement that is more sensitive to the income distribution among the poor. The measure used for the severity of poverty is the squared poverty gap ratio which is the total of the squared income shortfall, expressed in proportion to the poverty line, of families with income below the poverty threshold, divided by the total numbers of families. Severity of poverty defines how many families are located far below the poverty line. These people are labeled as the "poorest of the poor.

Table 3 - Health Related Issues in the Study Area

\begin{tabular}{lll}
\hline Variables & Frequency & Percentage \\
\hline Access to health care? & & 81.21 \\
Yes & 134 & 18.78 \\
No & 31 & 38.79 \\
Health facilities available and accessed by Farmers. & 9.09 \\
Clinic & 64 & 25.45 \\
Medical store & 15 & 18.78 \\
Private hospital & 42 & 7.89 \\
PHC & 31 & 41.90 \\
General hospital & 13 & 58.10 \\
Child Motility Issues & & 36.23 \\
Yes & 69 & 24.64 \\
No & 96 & 23.19 \\
No of Motility Experienced by Farmers & 96.94 \\
$1-2$ & & 15.94 \\
3-4 & 25 & \\
7-6 & 17 & 50.30 \\
Sub total & 16 & 49.70 \\
Use of alternative Medicine & 11 & \\
Yes & 69 & 14.55 \\
No & & 50.01 \\
Reasons for using alternative Medicine & 83 & 16.97 \\
Affordable & 8.64 \\
More Effective & 82 & 6.50 \\
Lack of money for health facilities & 100 \\
Preferred & & \\
\hline Total & 12 & \\
\hline
\end{tabular}

Table 4 - Poverty measures, Elasticity, and Related Statistics

\begin{tabular}{|c|c|c|c|}
\hline Poverty Indices & $\begin{array}{l}\text { Estimated } \\
\text { value }\end{array}$ & $\begin{array}{l}\text { Elasticity with respect to mean } \\
\text { consumption }\end{array}$ & $\begin{array}{l}\text { Elasticity with respect to } \\
\text { inequality }\end{array}$ \\
\hline $\begin{array}{l}\text { Poverty Incidence (P0) } \\
\text { Poverty Gap (P1) } \\
\text { Poverty Severity (p2) } \\
\text { Mean Per capita income } \\
\text { per year } \\
\text { Poverty Line } \\
\text { Gini index }\end{array}$ & 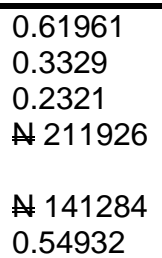 & $\begin{array}{l}-0.6843 \\
-0.8612 \\
-0.8684\end{array}$ & $\begin{array}{l}0.202782 \\
1.551524 \\
2.849953\end{array}$ \\
\hline
\end{tabular}

Source: Data Analysis, 2021. 
The Table 5 presents the disaggregated farmers poverty status by selected household characteristics. The result revealed that the inequality among the males (0.5274) was slightly lower than those of their female (0.5440) counterparts, implying that there was a higher variation in spending among the female than their male counterparts. However, poverty incidence (proportion of males living below the poverty line) among the male headed households $(67.45 \%)$ was higher than the females $(49.51 \%)$ headed households. These findings agreed with those obtained by (Ayinde, 2003 and Adekoya, 2014). This findings is however at variance with the general opinion that poverty incidence ought to be higher among female headed households. Adekoya (2014), however observed that most female farmers engage in secondary occupation such as trading which tend to stabilize and generate additional income for the household's consumption expenditure. Furthermore, the study revealed that depth of poverty and severity of poverty among the women were higher compared with their male counterparts meaning that the women poverty situation require targeted attention. For instance, Dollar and Kraay (2001) investigated the extent to which the poor in the society can benefit from growth in the economy. It was observed that the income of the poor rises consistently with the average income in the economy. They affirm that, although growth benefits the poor in the same way as every other person, growth is not all that is necessary to improve the life of the poor. There is a need for implementation of intervention mechanisms to improve the lives of the poor in the society (Jaiyeola and Choga, 2020). The women therefore, require targeted policies to bring them to the poverty line.

Table 5 - Income Inequality and Poverty Profile by Demographic Indicators

\begin{tabular}{|c|c|c|c|c|}
\hline Variables & $\begin{array}{l}\text { Inequality } \\
\text { Gini index }\end{array}$ & $\begin{array}{l}\text { Poverty } \\
\text { PO }\end{array}$ & P1 & P2 \\
\hline Pooled & 0.5493 & 0.6196 & 0.3329 & 0.2321 \\
\hline Male & 0.5274 & 0.6745 & 0.2598 & 0.1903 \\
\hline Female & 0.5440 & 0.4951 & 0.3651 & 0.2505 \\
\hline \multicolumn{5}{|l|}{ Location } \\
\hline Urban & 0.5450 & 0.4960 & 0.3077 & 0.2688 \\
\hline Rural & 0.5451 & 0.6484 & 0.3388 & 0.2235 \\
\hline \multicolumn{5}{|l|}{ Status of Eduation } \\
\hline No formal Sch. & 0.5342 & 0.7878 & 0.3274 & 0.1591 \\
\hline Prim/Secondary & 0.6607 & 0.6250 & 0.4194 & 0.3520 \\
\hline Tariary & 0.4730 & 0.6046 & 0.3068 & 0.2013 \\
\hline \multicolumn{5}{|l|}{ Household Size } \\
\hline$<5$ & 0.4320 & 0.44021 & 0.1447 & 0.0837 \\
\hline $6-10$ & 0.5688 & 0.5959 & 0.3741 & 0.2830 \\
\hline$>10$ & 0.5615 & 0.9142 & 0.4772 & 0.3002 \\
\hline \multicolumn{5}{|l|}{ Marital Status } \\
\hline Married & 0.4914 & 0.6403 & 0.3145 & 0.2057 \\
\hline Unmarried & 0.5996 & 0.5880 & 0.3608 & 0.2723 \\
\hline \multicolumn{5}{|l|}{ Prim. Occupa } \\
\hline Farming & 0.6072 & 0.6892 & 0.4035 & 0.2969 \\
\hline Non-Farm & 0.3652 & 0.4348 & 0.1451 & 0.0599 \\
\hline
\end{tabular}

Source: Data Analysis, 2021.

There was no remarkable inequality difference in the spending of the urban (0.5450) and the rural $(0.5451)$ farmers although, poverty incidence $(64.84 \%)$ and depth $(0.3388)$ of the rural farmers were higher implying that the rural farmers were more poverty stricken compared to their urban counterparts supporting the view that poverty in the country is more of a rural phenomenon. Moreover, considering the status of education, the result indicate that farmers with secondary education had the highest income inequality with an index of (0.6607) compared to farmers with no-formal education (0.5342) and (0.4730) for those with tertiary education. This means that secondary school livers exhibit greater variability in income than others. The poverty pattern is such that, poverty incidence increases with lower educational status. For instance, about $78.8 \%$ of farmers with no-formal education live below the poverty line compared to $60.5 \%$ of those with tertiary institution. This result suggest that farmers with higher educational status take advantage of their privilege to boost their 
agricultural productivity. Education enhances better management decisions on innovations, information, social-net-working and market bargains that can translate into better welfare in the long run for such households.

The maize farmers presented income inequality, poverty status that increases with size of households. Households head with persons between $0-5$ had lower variability in spending with an index of $(0.4320)$ compared with about (0.56) for larger families. About $91.42 \%$ of those with family members greater than ten members live below poverty line. Where farming households are large with high dependency ratios, rather than the traditional labour reasons will plunge large families into poor per capita income hence poor welfare (Omonona,2009). Farmers that are not married i.e (single, Divorced, widow and widower) had higher income inequality (0.5996) but relatively lower poverty incidence $(0.5880)$ compared to the married household heads with $(0.4914)$ and poverty incidence of 0.6403$)$. Also, farmers with farming as their primary occupation, had greater spending divergence among them than those with farming as their secondary occupation which further suggest that farming households are poorer than that those with other occupation. Furthermore, poverty incidence was higher among married households $(0.6003)$ and farming families with farming as primary occupation with an index of (0.6892).

Table 6 - Logistic Regression and Marginal analysis of poverty Determinants among the Farmers

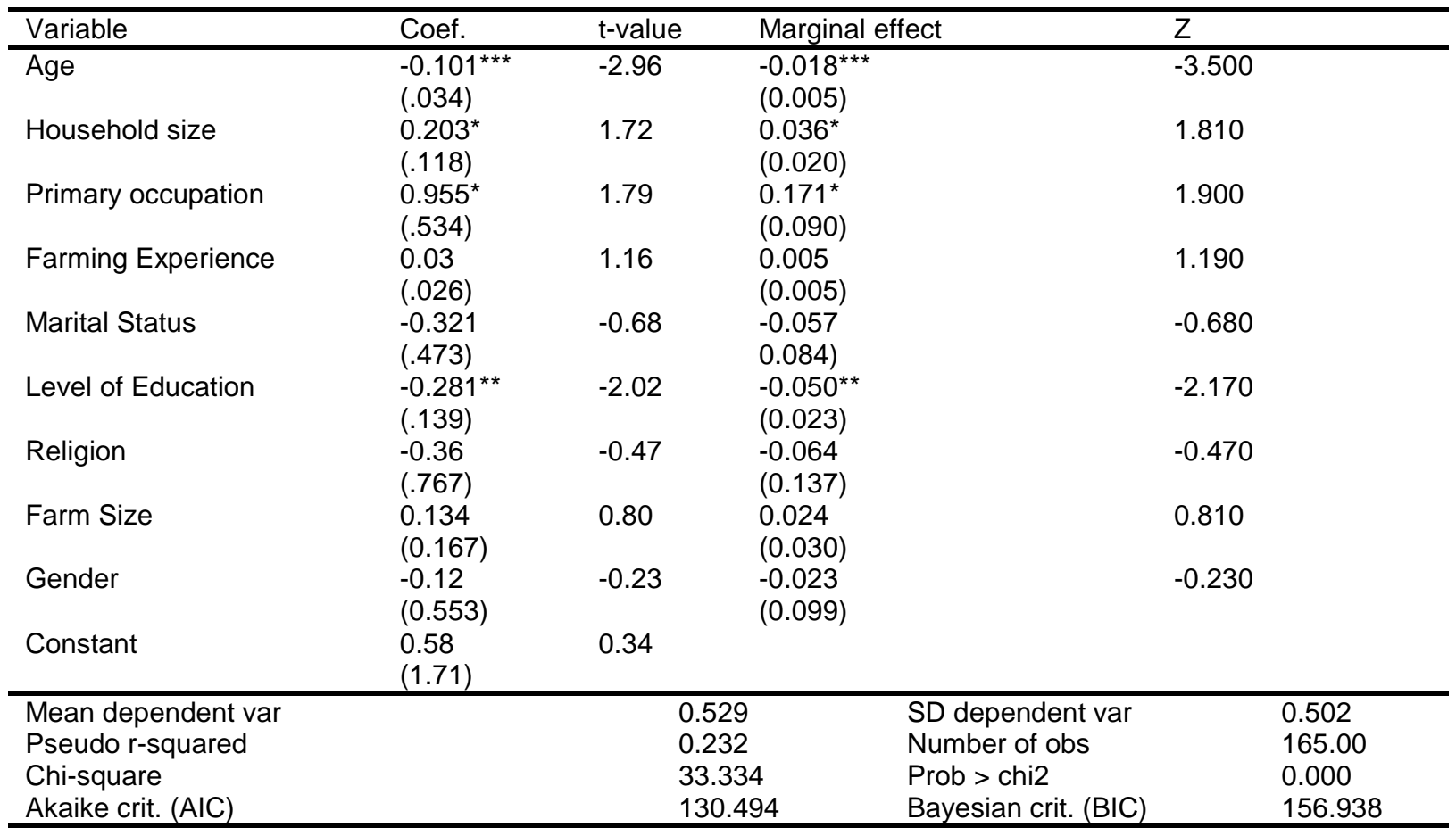

Source: Data Analysis, 2021. ${ }^{* *} p<.01,{ }^{* *} p<.05,{ }^{*} p<.1$

The various correlates of poverty in the study area were presented in Table 6 . The model chi-square indicates a good fit with some of the selected variables been statistically different from zero. Age $(p<0.01)$ of maize farmers, household's size $(p<0.1)$; Primary occupation $(p<0.1)$ status of education $(p<0.05)$ and marital status $(p<0.05)$ were found to influence the log likelihood of a maize farming household poverty status. Age of farmers, marital status and educational status were significant and negatively related to the poverty status, suggesting that a unit increase in any of these three variables significantly reduces the probability of being poor. Conversely, a unit increase in household size invariably increases the probability of being poor. The marginal analysis shows that a unit increase in age, marital status reduces the probability of being poor by $0.18 \%, 0.57 \%$ and $0.5 \%$ respectively. This result agrees with several earlier findings, (Ukoha, 2007; Yusuf et al, 2008; Adekoya, 2014; Ademiluyi,2014 and Ajewole, et al, 2016). According to Ukoha, 2007, age 
correlation with welfare is consistent with life cycle hypothesis which states that increase in age impact on management of income and consumption expenditure hence welfare. Ajewole et al. (2016), opined that experience is a function of age therefore, an increase in age suggests an increase in experience implying that older farmers may have perfected certain management operations and resource use to improve their productivity hence improved welfare.

Furthermore, (Yusuf et al., 2008; Ajewole et al, 2016) found educational status negatively related and significantly correlated with likelihood of being poor. For instance, Brucks (2003) argued that the level of education of a mother is likely to impact on household consumption than the level of education of a male head. Also, literature shows that education increases the stock of human capital, which in turn increases labor productivity and wages (Anyanwu, 2005). Thus, while an increase in illiteracy decreases opportunity of the poor to generate income, high literacy becomes an incentive to generate higher income hence better welfare. Adeyemi et al. (2018), noted that higher educational attainment has direct effect on enabling households access and conceptualize relevant information on technology adoption, improved farm practices, useful market information and productive enterprise combinations that eventually dove tail into better welfare. In relation to household size, results obtained in this study revealed that a unit increase in household size will increase poverty by $0.36 \%$. Large households have implications for high dependency ratio and leads to low per capita income.

This result is consistent with the findings of (Adekoya, 2014 and Ajewole et al., 2016) but at variance with those of (Akinlade et al., 2015) who observed that an increase in household size decreases the probability of being poor in his study of poverty and inequality among farming households in southwestern Nigeria.

\section{CONCLUSION}

In potentially achieving poverty reduction in the study area, emphasis on economic growth should not be limited to the trickle-down doctrine, which suggests that assistance to the wealthy such as tax benefits or increasing supply will boost economic growth, the benefits of which is assumed to reach the poor. Rather, policy should include broad-based sustainable poverty reduction through improving the capabilities of the poor through targeted project implementation. This is the core of the pro-poor growth principle which stresses developing programs that target meeting the needs of the majority in the population, especially the poorest of the people. Therefore, this study which centered on welfare and poverty status among maize farming households in Lere L.G.A. Kaduna State, established that Poverty measures in this study show a more responsiveness to changes in inequality with values than to changes in income. Also, age of the farmers, households' size, primary occupation and educational status were the factors that significantly influenced the likelihood of being poor. Therefore, policies that enhance redistribution of income and reduce inequality among the farming households would uplift more individuals around the poverty line.

\section{REFERENCES}

1. Abdul-Mamin A; Shamshiry E (2014) Linking sustainable livelihood to natural resources and Governance, the scale of poverty in the Muslim world, Springer.

2. Adejobi, A. O. (2004). Rural poverty, food production and demand in Kebbi state, Nigeria. Unpublished Ph.D thesis, Department of Agricultural Economics, University of Ibadan

3. Adekoya, (2014). Analysis of Farm Households Poverty Status in Ogun States, Nigeria, Asian Economic and Financial Review. 4(3).

4. Ademiluyi (2014). Determinants of Smallholder Farmers' Welfare in Plateau State, Nigeria. International Journal of Innovative Agriculture \& Biology Research 2 (4):11-16.

5. Adeyemi A.O, Adebayo O., Kehinde O. and Abiola J.A (2018). Poverty and Rural Inequality in Rural Agrarian Households of Southwestern Nigeria. The Gender Perspective. Open Agricultural Journal 13:51-63. 
6. Ajewole, O.O.; Ojehomon, V.E.T; Ayinde, O.E.; Agboh-Noameshie, A.R., Diagne, A. (2016). Gender Analysis of Poverty Among Rice Farming Household in Nigeria Rice hub. $5^{\text {th }}$ International Conference of AAAE, 23-26 Sept. 2016. Held at international conference Center, Addis Ababa EthiopiaAkinlade et al., 2015).

7. Anyanwu, J. C. (2005), "Rural Poverty in Nigeria: Profile, Determinants and Exit Paths" African Development Review, Vol. 17, No.3, December, pp. 435-460.

8. Ataguba J., Fonta W.M and H.E Ichoku (2011). The Determinants of Multidimensional Poverty in Nsukka, Nigeria, Poverty and Economic Policy Research Network. SSRN Electronic Journal, https://www.researchgate.net/publication/228155725.

9. Amaza P.S, Olayemi A.O, Adejobi Y, Iheanacho I (2007). Baseline Socioeconomic Survey Report: Agriculture in Borno state, Nigeria. International Institute of tropical Agriculture, Ibadan, Nigeria.

10. Arimah, B.C. (2004). Poverty reduction and human development in Africa. J. Dev.5:399415 Federal Office of Statistics (FOS) (1999); poverty profile for Nigeria, federal office of statistic, Lagos Nigeria.

11. Ayinde, I.A., 2003. Analysis of poverty level among farmers in Ogun State, Nigeria, Asset Series A, 3(3): 27-35.

12. Ayinde, O.E, Muchie, M. Babatunde R.O, Adeyemi M.O, Ayinde K and Ibitoye, Olalekan (2012). Analysis of Income inequality in Nigerian Agricultural Economy: A case Study of Ekiti State. Conferences of International Association of Agricultural Economists Held at Foz do Iguacu, Brazil August 18-24.

13. Akinlade, R. J., Adeyonu, A. G. and Carim-Sanni, A (2015). Income Inequality and Poverty among Farming Households In Southwest, Nigeria International Journal of Agricultural Economics and Rural Development. IJAERD 7(1).

14. Alkire, S. and S. Seth (2008). Multidimensional poverty measurement and BPL methods in India: A comparison of methods. OPHI Working Paper No. 15, University of Oxford.

15. Alkire, S., and Foster, J. (2008). Counting and Multidimensional Poverty Measurement. Oxford Poverty \& Human Development Initiative (OPHI) Working Paper Series, United Kingdom $\mathrm{P} 33$.

16. Aigbokhan, B. (2008) Poverty, growth and inequality in Nigeria: A case study. African Economic Research Consortium (AERC).Nairobi, Kenya.

17. Balogun O. S, Usman M. B, Ayodele J. T, Aasa, O.S, and Anamayi, R. (2020). Fuelwood Consumption and Clean Cooking fuel Poverty in Kaduna State, Nigeria: Implication for Sustainable Forest Management. Journal of Forestry Research and Management. Vol. 17(2).148-158.

18. Balogun, O.L (2011). Influence of social capital and microcredit on rural household poverty in southwestern Nigeria.Unpublished Ph.D thesis in the Department of Agricultural Economics, University of Ibadan, Ibadan, $170 \mathrm{pp}$.

19. Bruck, T, (2003):Household Cropping Choice and the Determinants of Income and Consumption in Post War Rural Mozambique. A Paper Submitted at the European Economic Association Annual Meeting Instockholm.

20. Chamhuri, N.H, Karim H.A and Hamdan H (2012). Conceptual Framework of Urban Poverty Reduction: A Review of Literature. Procedia - Social and Behavioral Sciences 68 (2012) $804-814$.

21. Friday S. Ebong, Fidelis O. Ogwumike (2013). Economic Growth and Poverty Reduction in Nigeria: An Empirical Investigation. Journal of Economic and Sustainable Development $4: 7$.

22. Food and Agriculture Organization (FAO). (2015). State of food insecurity in the World, FAO, 2015, P 44.

23. Foster, J.E., J. Greer and E. Thorbeck, 1984. A class of decomposable poverty measures. Econometrica, 52(1): 761-766.

24. Jaiyeola O.A and Choga I. (2020). Assessment of poverty incidence in Northern Nigeria. Journal of Poverty. DOI: 10.1080/10875549.2020.1783424 
25. United Nation Development Programme (UNDP). (2010). HumanDevelopment Report Nigeria, 2008-2009. Achieving Growth with Equity. United Nations Development Programme P 52.

26. Ewhrudjakpor C., (2013) Poverty and its alleviation The Nigerian experience. International Social Work volume 51(4). https://doi.org/10.1177/0020872808090245

27. Maduagwu, A. (2007). Taking IT Global-Panorama-Women and poverty. Retrieved on 23rdAugust, 2011 from http://www.tigweb.org/express/panorama/article.html.11/23/2009

28. Morduch J. and T. Sicular (2002), Rethinking inequality decomposition, with evidence from Rural China, Economic Journal 112(476), 93-106.

29. National Bureau of Statistics, (2008). Poverty profile for Nigeria. Nigerian bureau of statistics. Abuja, Nigeria.

30. KDBS, (2018). Kaduna State Statistical Year Book.

31. Omonona, B. T. (2001). The Determinant of Poverty among Farming Households in Kogi State, Nigeria. Unpublished Ph. D. Thesis, University of Ibadan, Ibadan.

32. Omonona B.T, Amao J.O and Bamimore J.A (2014) Social Capital and Farming Household Welfare in Oyo State, Nigeria. International Journal of Business and Social Sciences 5: 9(1).

33. Omonona B.T. (2009). Knowledge Review on Poverty and Rural Development in Nigeria.The Nigeria Strategy Support Program (NSSP) Background Papers IFPRI. NSSP Report 003.

34. Obadan, M. I. (2001). Poverty Reduction: the way forward. Central Bank of Nigeria Economic and Financial Review. 39 (4) 159 - 188.

35. Oyekale, A. S., \& Okunmadewa, F. Y. (2008). Fuzzy Set Approach to Multidimensional Poverty Analysis in Abia State, Nigeria. Journal of Applied Sciences, 3(7), 490-495.

36. Park, H.M (2010). Regression Models for Binary Dependent Variables Using Stata, SAS, R, LIMDEP, and SPSS. Working paper. The University Information Technology Services (UITS) Center for Statistical and Mathematical Computing.

37. Ukoha,O.O,Mejeha,R.O and Nte,I.N. (2007 ): Determinants of Farmers Welfare in Ebonyi State, Nigeria. Pakistan Journal of Social Science 4 (3):351-354.

38. World Bank (2000) 'Voices of the Poor', World Development Report 2000/2001: Attacking Poverty. Washington, DC: World Bank.

39. World Bank, 2000, World Development Report (New York and Washington: Oxford University Press and World Bank).

40. Yusuf S.A, Adesanoye and D.O. Awotide (2008). Assessment of Poverty among Urban Farmers in Ibadan Metropolis, Nigeria. Journal of Human Ecology 24(3); 201-207. 